\title{
Spectrum of Aminoglycoside Modifying Enzymes in Gram-Negative Bacteria Causing Human Infections
}

\author{
Kayanam Vijaya Lalitha Aishwarya ${ }^{1}$ Pacha Venkataramana Geetha ${ }^{1} \quad$ Sudalai Eswaran ${ }^{1}$ Shanthi Mariappan ${ }^{1}$ \\ Uma Sekar ${ }^{1}$ \\ ${ }^{1}$ Department of Microbiology, Sri Ramachandra Institute for \\ Higher Education and Research, Chennai, Tamil Nadu, India

\begin{abstract}
Address for correspondence Aishwarya KVL, MSc, Department of Microbiology, Sri Ramachandra Institute for Higher Education and Research, Porur, Chennai 600116, Tamil Nadu, India
\end{abstract} \\ (e-mail: mailaishmicro@gmail.com).
}

\begin{abstract}
Introduction Aminoglycosides are formidable broad-spectrum antibiotics used in clinical settings; woefully their usage has been reduced by the emergence and distribution of resistance mainly due to aminoglycoside modifying enzymes (AME).

Purpose This study was performed to determine the diverse prevalence of AME and their pattern of occurrence in the clinical isolates of gram-negative bacteria. This study also aimed to detect the presence of AMEs that are prevalent in gram-positive bacteria, among gram negatives.

Materials and Methods A total number of 386 clinical isolates were included in this study. Polymerase chain reaction revealed the prevalence rate of AMEs screened

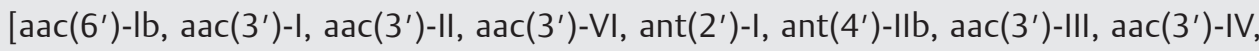

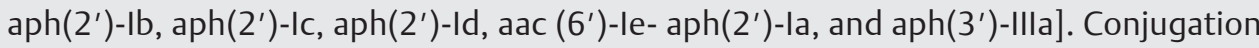
experiment was performed for the clinical isolates which harbored any one of the AME which was prevalent in gram-positive bacteria [aph(3')-IIla, aac(6')-le-aph(2')-la].

Results $\operatorname{aac}\left(6^{\prime}\right)-\mathrm{Ib}$ is the most prevalent AME, followed by aac $\left(3^{\prime}\right)-\mathrm{I}, \mathrm{aph}\left(3^{\prime}\right)-\mathrm{VI}$,

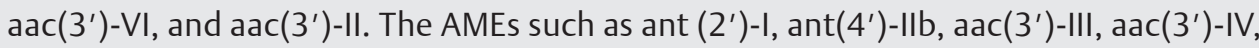
$\mathrm{aph}\left(2^{\prime}\right)-\mathrm{Ib}, \mathrm{aph}\left(2^{\prime}\right)-\mathrm{Ic}$, and aph(2')-Id were not established in our study isolates. The

Keywords

- AME

- conjugative plasmid

- GP AME

- gram-negative bacteria rate of prevalence of aph( $\left(3^{\prime}\right)$-IIla, aac $\left(6^{\prime}\right)$-le-aph $\left(2^{\prime}\right)$-la-the AMEs encountered in grampositive and their co-existence was $19.68 \%$ and the conjugation experiment revealed their transfer via plasmids.

Conclusion This is the first report from India revealing the presence and prevalence of AMEs which are often encountered among gram-positive bacteria in gram negatives and their presence on conjugative plasmids.
\end{abstract}

\section{Introduction}

Aminoglycosides (AG) play an important and adjunctive role in the treatment of life-threatening infections owing to their synergetic and broad-spectrum activity against both gram-positive and gram-negative bacteria. This group of antibiotics bind to the ribosomes of the bacteria thereby leading to inhibition of protein synthesis and consequent bacterial cell death. Their extensive use has resulted in development and dissemination of resistance to this class of antimicrobials.
The mechanisms of aminoglycoside resistance are diverse. The most common mechanism is the inactivation of the antibiotic by a family of enzymes named aminoglycoside modifying enzymes (AME). ${ }^{1}$ The AMEs catalyze the modification of the AGs at- $\mathrm{OH}$ or- $\mathrm{NH}_{2}$ groups of the 2-deoxystreptamine nucleus or sugar moieties via acetyltransferases, nucleotidyltransferases, and phosphotransferases ${ }^{2}$ which modify the drug, resulting in poor binding to the ribosome thereby allowing the bacteria to survive in the presence of the drug. ${ }^{3}$

Besides the AMEs, other resistance mechanisms include change in bacterial membrane permeability, expression of 
efflux pumps, and methylation through 16S ribosomal RNA methyltransferases. These 16S rRNA methyltransferases are often encountered in multidrug-resistance gram negatives especially among New Delhi Metallo betalactamase producers. $^{4}$

There are more than 85 AMEs reported in both gram-positive and gram-negative bacteria. A few among them, particularly ant(2')-I, aac(6')-I, aac(3')-I to IV, and aac(3')-VI, undergo continuous mutation ${ }^{5}$ leading to the generation of new AME variants which utilize a variety of AGs as substrates, cleave them, and make them ineffective. These AMEs virtually spread to all bacterial types through conjugative plasmids, natural transformation, or transduction. ${ }^{6}$

Dissemination of AMEs via plasmids has been reported in developed countries. ${ }^{7}$ Since there is a paucity of information from India regarding the prevalence and type of AMEs in gram-negative bacteria, the present study was undertaken to determine their prevalence among clinical isolates of gram-negative bacteria in a tertiary care center.

There are some AMEs which were originally detected in gram-positive (GP AMEs) bacteria and characteristically occur in them. They are aph(3')-IIla that is the most prevalent and a bifunctional AME aac(6')-Ie-aph(2')-Ia. They confer resistance to a broad spectrum of AGs. There have been reports of their presence in gram-negative clinical isolates from Slovakia and Germany. ${ }^{8}$ Hence, this study was aimed to detect their presence in gram-negative bacteria.

\section{Materials and Methods}

\section{Ethical Approval}

The study was approved by the Institutional Ethical Committee (IEC-NI/15/APR/6/18).

\section{Bacterial Isolates}

A total of 386 amikacin-resistant gram-negative bacteria which were clinically significant and nonduplicate were collected over a period of 3 years from June 2015 to September 2018. All the isolates were speciated based on conventional or VITEK-2 system (Vitek-2 GN-card; BioMerieux).The bacterial isolates included were obtained from different clinical sources such as blood (14), urine (176), exudate (162), and respiratory secretion $\mathrm{s}(34)$

\section{Antibiotic Susceptibility Testing}

Disk diffusion test was performed in accordance with the Clinical Laboratory Standard Institute (CLSI, 2016). ${ }^{9}$ The AGs tested were amikacin $(30 \mu \mathrm{g})$, gentamicin $(10 \mu \mathrm{g})$, tobramycin $(10 \mu \mathrm{g})$, and netilmicin $(10 \mu \mathrm{g})$ (HiMedia Laboratories).

\section{Polymerase Chain Reaction}

Nine sets of uniplex and two sets of multiplex polymerase chain reactions (PCRs) were performed for AMEs using previously described primers and conditions. ${ }^{10-14}$ The primers used for different sets of genes, their annealing temperatures, and the amplicon sizes are listed in - Table $\mathbf{1}$.
Seven sets of uniplex PCRs were performed for 16SrRNA methyltransferase using primers established in our earlier study. ${ }^{15}$

Each reaction volume contained $2 \mu \mathrm{L}$ of the deoxyribonucleic acid (DNA) template added to the master mix which includes $10 \mathrm{pmol}$ of the forward and reverse primers (SigmaAldrich), $10 \mathrm{~mm}$ deoxyribonucleotide triphosphate (Takara), $5 \mathrm{U}$ Taq polymerase (Takara), and $10 \times$ buffer with $\mathrm{MgCl}_{2}$ (Takara).

Amplification of the reactions was performed under the following conditions: initial denaturation at $95^{\circ} \mathrm{C}$ for 4 minutes, followed by 32 cycles of denaturation at $94^{\circ} \mathrm{C}$ for 30 seconds, annealing based on the primer employed for 30 seconds with an extension at $72^{\circ} \mathrm{C}$ for 50 seconds, and a final extension for one cycle at $72^{\circ} \mathrm{C}$ for 5 minutes. The PCR product was then run on a $1.5 \%$ agarose gel for detection of the amplified fragment.

\section{Template DNA Preparation}

A single bacterial colony was inoculated into Luria-Bertani broth (HiMedia Laboratories) and incubated overnight at $37^{\circ} \mathrm{C}$, and it was then centrifuged at $10,000 \mathrm{rpm}$ for 10 minutes. The pellet was re-suspended in $250 \mu \mathrm{L}$ of Millipore water, boiled at $100^{\circ} \mathrm{C}$ for 10 minutes, and cooled and centrifuged at $10,000 \mathrm{rpm}$ for 10 minutes. The supernatant served as the template DNA. ${ }^{16}$

\section{DNA Sequencing}

PCR-positive amplicons were purified and sequenced. The sequenced strains served as positive controls. Sequencing was done by BigDye 3.1 cycle sequencing kit using Sanger AB13730 XL DNA analyzing instrument (AgriGenome). The nucleotide sequences were aligned using the Bioedit sequence program (product version 7.0.5.3) and were compared with the basic alignment search tool available at the National Center for Biotechnology Information website (www.ncbi.nIm.nih.gov).

\section{Conjugation Assay}

Bacterial conjugation was performed at $37^{\circ} \mathrm{C}$ for the clinical isolates which harbored either one of the GP AMEs [aph(3')-IIIa and $\operatorname{aac}\left(6^{\prime}\right)$-Ie-aph(2')-Ia]. Azide-resistant Escherichia coli J53 served as recipient. The transconjugants were selected on MacConkey agar plate containing $100 \mu \mathrm{g}$ of sodium azide (HiMedia Laboratories) along with $4 \mu \mathrm{g}$ of amikacin. ${ }^{17}$ The transferability of the AMEs through plasmid in transconjugants was confirmed by PCR.

\section{Result}

The study isolates includes E. coli $(n=79)$, Klebsiella pneumonia ( $n=149)$, Klebsiella oxytoca $(n=4)$, Citrobacter freundii $(n=2)$, Enterobacter cloacae $(n=11)$, Proteus mirabilis $(n=5)$, Proteus vulgaris $(n=2)$, Providencia rettgeri $(n=16)$, Morganella morganii $(n=12)$, Pseudomonas aeruginosa ( $n=63)$, Pseudomonas fluorescens $(n=4)$, Pseudomonas putida $(n=1)$, and Acinetobacter baumannii $(n=38)$. All the 
Table 1 Primers used for performing PCR for amplifying AME genes

\begin{tabular}{|c|c|c|c|c|}
\hline Simplex set & Gene & Primer & $\begin{array}{l}\text { Annealing temperature } \\
\left({ }^{\circ} \mathrm{C}\right)\end{array}$ & $\begin{array}{l}\text { Amplicon size } \\
\text { (bp) }\end{array}$ \\
\hline 1 & $\mathrm{aac}\left(6^{\prime}\right)-\mathrm{lb}$ & $\begin{array}{l}\text { F-TTG CGA TGC TCT ATG AGT GGC TA } \\
\text { R-CTC GAA TGC CTG GCG TGT TT }\end{array}$ & 60 & 482 \\
\hline 2 & $\operatorname{aph}\left(3^{\prime}\right)-\mathrm{VI}$ & $\begin{array}{l}\text { F-ATGGAATTGCCCAATATTATT } \\
\text { R-TCAATTCAATTCATCAAGTTT }\end{array}$ & 55 & 780 \\
\hline 3 & $\operatorname{aac}\left(3^{\prime}\right)-1$ & $\begin{array}{l}\text { F-TTC ATC GCG CTT GCT GCY TTY } \\
\text { R-GC CAC TGC GGG ATC GTC RCC RTA }\end{array}$ & 56 & 239 \\
\hline 4 & $\operatorname{aac}\left(3^{\prime}\right)-11$ & $\begin{array}{l}\text { F-GCG CAC CCC GAT GCM TCS ATG G } \\
\text { R-GGC AAC GGC CTC GGC GTA RTG SA }\end{array}$ & 58 & 370 \\
\hline 5 & $\operatorname{aac}\left(3^{\prime}\right)-111$ & $\begin{array}{l}\text { F-GAC AAT GGC GTG CTA SCS GAR T } \\
\text { R-C CAG ATG CTC GGC ATG RTG SAG }\end{array}$ & 58 & 241 \\
\hline 6 & $\operatorname{aac}\left(3^{\prime}\right)-\mathrm{IV}$ & $\begin{array}{l}\text { F-GAC GAC GAG CCG TTC GAY CC } \\
\text { R-C CT CAA CTC GGC AAG ATG SAG }\end{array}$ & 58 & 280 \\
\hline 7 & $\operatorname{aac}\left(3^{\prime}\right)-\mathrm{VI}$ & $\begin{array}{l}\text { F-GCC CT CCC GAC GCA TCS ATG G } \\
\text { R-CGC CAC CGC TTC GGC ATA RTG SA }\end{array}$ & 55 & 780 \\
\hline 8 & ant(2')-I & $\begin{array}{l}\text { F-TGG GCG ATC GAT GCA CGG CTR G } \\
\text { R-AA AGC GGC ACG CAA GAC CTC MAC }\end{array}$ & 58 & 428 \\
\hline 9 & ant $\left(4^{\prime}\right)-$ IIb & $\begin{array}{l}\text { F TAT CTC GGC GGT CGA GT } \\
\text { R CAC GCG GGG AAA CGC GAG AA }\end{array}$ & 60 & 364 \\
\hline \multirow[t]{2}{*}{ Multiple $\times 1$} & $\begin{array}{l}\operatorname{aac}\left(6^{\prime}\right)-\mathrm{le}- \\
\operatorname{aph}\left(2^{\prime}\right)-\mathrm{la}\end{array}$ & $\begin{array}{l}\text { F-CAGGAATTTATCGAAAATGGTAGAAAAG } \\
\text { R-CACAATCGACTAAAGAGTACCAATC }\end{array}$ & \multirow[t]{2}{*}{55} & 369 \\
\hline & $\operatorname{aph}\left(3^{\prime}\right)-$-IIla & $\begin{array}{l}\text { F-GGCTAAAATGAGAATATCACCGG } \\
\text { R-CTTTAAAAAATCATACAGCTCGCG }\end{array}$ & & 523 \\
\hline \multirow[t]{3}{*}{ Multiple $\times 2$} & $\mathrm{aph}\left(2^{\prime}\right)-\mathrm{Ib}$ & $\begin{array}{l}\text { F-CTTGGACGCTGAGATATATGAGCAC } \\
\text { R-GTTTGTAGCAATTCAGAAACACCCTT }\end{array}$ & \multirow[t]{3}{*}{58} & 867 \\
\hline & $\operatorname{aph}\left(2^{\prime}\right)-\mathrm{Ic}$ & $\begin{array}{l}\text { F-CCACAATGATAATGACTCAGTTCCC } \\
\text { R-CCACAGCTTCCGATAGCAAGAG }\end{array}$ & & 444 \\
\hline & $\operatorname{aph}\left(2^{\prime}\right)$-Id & $\begin{array}{l}\text { F-GTGGTTTTTACAGGAATGCCATC } \\
\text { R-CCCTCTTCATACCAATCCATATAACC }\end{array}$ & & 641 \\
\hline
\end{tabular}

Abbreviations: AME, aminoglycoside modifying enzymes; PCR, polymerase chain reaction.

study isolates exhibited resistance to all the tested AGs as determined by disk diffusion method.

PCR identification revealed the prevalence of 16SrRNA methyltransferases and AMEs, of which all the clinical isolates carried one or more than one 16SrRNA methyltransferases (data were not disclosed in this study). Of the study isolates, 46.63\% harbored single AME and 38.86\% harbored more than one AME. The distributions of these enzymes among the different gram-negative species were tabulated (-Table 2).

Interestingly GP AMEs namely aph(3')-IIIa and aac(6')-Ie$\operatorname{aph}\left(2^{\prime}\right)$-Ia were identified in this study isolates. They were detected in 3.88 and $8.03 \%$ of the study isolates, respectively (-Table 3). Co-occurrence of both of these enzymes was encountered in $7.77 \%$.

However, AMEs such as ant(2')-I, ant(4')-IIb, aac(3')-III, aac(3')-IV, aph(2')-Ib, aph(2')-Ic, and aph(2')-Id were not encountered in any of the study isolates.

Conjugation assay was successful in all the clinical isolates tested which harbored the GP AMEs.

\section{Discussion}

AGs play a vital role as monotherapy and in combination for the treatment of majority of bacterial infection. The resistance to AGs in bacteria is predominantly due to the AMEs. ${ }^{1}$

All the 386 clinical isolates were resistant to all the tested AGs. They did not exhibit any substrate-specific hydrolyzing profile which is commonly encountered in AME. This is attributable to the presence of 16S rRNA methyltransferases which confer resistance to all AGs. ${ }^{4}$

The prevalence of aac $\left(6^{\prime}\right)-$ lb singly and in combinations with other AME is higher (-Table 2) when compared with previous reports from Iran, China, and Spain which had 31. $6,19.6,4.2 \%$ of aac $\left(6^{\prime}\right)-1 b$, respectively. ${ }^{18-20}$ The AME $\operatorname{aac}\left(3^{\prime}\right)-\mathrm{I}$ was the second most prevalent gene singly and in also combination(6.21 and 17.61\%). This enzyme has been reported in large number of gram-negative clinical isolates previously. ${ }^{2}$ The enzyme aph(3')-VI, first identified in A. baumannii in $1988,{ }^{21}$ was the third most prevalent gene. 
Table 2 Distribution of AME genes and their combination among different gram negatives

\begin{tabular}{|c|c|c|c|c|c|c|c|c|c|}
\hline \multirow{2}{*}{$\begin{array}{l}\text { Aminoglycoside } \\
\text { modifying } \\
\text { enzyme genes }\end{array}$} & \multicolumn{9}{|c|}{ Total number of gram negatives $(n=386)$} \\
\hline & $\begin{array}{l}\text { E. coli } \\
(n=79)\end{array}$ & $\begin{array}{l}\text { Klebsiella } \\
(n=153)\end{array}$ & $\begin{array}{l}\text { Citrobacter } \\
(n=2)\end{array}$ & $\begin{array}{l}\text { Enterobacter } \\
(n=11)\end{array}$ & \begin{tabular}{|l|} 
Proteus \\
$(n=7)$
\end{tabular} & $\begin{array}{l}\text { Providencia } \\
(n=16)\end{array}$ & $\begin{array}{l}\text { Morganella } \\
(n=12)\end{array}$ & $\begin{array}{l}\text { Pseudomonas } \\
(n=68)\end{array}$ & $\begin{array}{l}\text { Acinetobacter } \\
(n=38)\end{array}$ \\
\hline aac $\left(6^{\prime}\right)-\mathrm{lb}(n=135)$ & 22 & 59 & 2 & 5 & 4 & 4 & 6 & 21 & 12 \\
\hline $\operatorname{aac}\left(3^{\prime}\right)-I(n=24)$ & 7 & 4 & - & 1 & 3 & 3 & 1 & 4 & 1 \\
\hline $\operatorname{aph}\left(3^{\prime}\right)-\mathrm{VI}(n=13)$ & - & 5 & - & - & - & - & 1 & 7 & - \\
\hline $\operatorname{aac}\left(3^{\prime}\right)-\mathrm{VI}(n=5)$ & - & - & - & 3 & - & - & - & - & 2 \\
\hline $\operatorname{aac}\left(3^{\prime}\right)-\| 1(n=3)$ & - & 3 & - & - & - & - & - & - & - \\
\hline $\begin{array}{l}\operatorname{aac}\left(6^{\prime}\right)-1 \mathrm{lb}+ \\
\operatorname{aac}\left(3^{\prime}\right)-1(n=68)\end{array}$ & 30 & 24 & - & 1 & - & 1 & - & 10 & 2 \\
\hline $\begin{array}{l}\operatorname{aac}\left(6^{\prime}\right)-\mathrm{Ib}+ \\
\operatorname{aph}\left(3^{\prime}\right)-\mathrm{VI}(n=47)\end{array}$ & 6 & 24 & - & 1 & - & - & 2 & 7 & 7 \\
\hline $\begin{array}{l}\operatorname{aac}\left(6^{\prime}\right)-\mathrm{Ib}+ \\
\operatorname{aac}\left(3^{\prime}\right)-11(n=8)\end{array}$ & 3 & 5 & - & - & - & - & - & - & - \\
\hline $\begin{array}{l}\operatorname{aph}\left(3^{\prime}\right)-\mathrm{VI}+ \\
\operatorname{aac}\left(3^{\prime}\right)-I(n=3)\end{array}$ & - & - & - & - & - & - & - & - & 3 \\
\hline $\begin{array}{l}\operatorname{aac}\left(6^{\prime}\right)-\mathrm{Ib}+ \\
\operatorname{aph}\left(3^{\prime}\right)-\mathrm{VI}+ \\
\operatorname{aac}\left(3^{\prime}\right)-\mathrm{I}(n=20)\end{array}$ & 2 & 7 & - & - & - & - & - & 7 & 4 \\
\hline $\begin{array}{l}\operatorname{aac}\left(6^{\prime}\right)-|-| b+ \\
\operatorname{aac}\left(3^{\prime}\right)-I^{+} \\
\operatorname{aac}\left(3^{\prime}\right)-I I(n=1)\end{array}$ & 1 & - & - & - & - & - & - & - & - \\
\hline $\begin{array}{l}\operatorname{aac}\left(6^{\prime}\right)-\mathrm{Ib}+\mathrm{ac}\left(3^{\prime}\right)-\mathrm{I}+ \\
\operatorname{aac}\left(3^{\prime}\right)-\mathrm{II}+ \\
\operatorname{aph}\left(3^{\prime}\right)-\mathrm{VI}(n=3)\end{array}$ & 3 & - & - & - & - & - & - & - & - \\
\hline
\end{tabular}

Abbreviations: AME, aminoglycoside modifying enzymes.

Table 3 Study isolates associated with AMEs prevalent in gram-positive bacteria

\begin{tabular}{|l|l|l|l|l|l|l|l|l|l|}
\hline \multirow{2}{*}{$\begin{array}{l}\text { Gram-positive } \\
\text { AMEs }\end{array}$} & $\begin{array}{l}\text { E. coli } \\
(n=79)\end{array}$ & $\begin{array}{l}\text { Klebsiella } \\
(n=153)\end{array}$ & $\begin{array}{l}\text { Citrobacter } \\
(n=2)\end{array}$ & $\begin{array}{l}\text { Enterobacter } \\
(n=11)\end{array}$ & $\begin{array}{l}\text { Proteus } \\
(n=7)\end{array}$ & $\begin{array}{l}\text { Providencia } \\
(n=16)\end{array}$ & $\begin{array}{l}\text { Morgonella } \\
(n=12)\end{array}$ & $\begin{array}{l}\text { Pseudomonas } \\
(n=68)\end{array}$ & $\begin{array}{l}\text { Acinetobacter } \\
(n=38)\end{array}$ \\
\hline $\begin{array}{l}\text { aph(3')-IIla } \\
(n=15)\end{array}$ & - & 7 & - & - & - & - & - & 8 & - \\
\hline $\begin{array}{l}\text { aac(6')-le- } \\
\text { aph(2')-la } \\
(n=31)\end{array}$ & 4 & 5 & - & - & 2 & 5 & 2 & 8 & 5 \\
\hline $\begin{array}{l}\text { aph(3')-IIla }+ \\
\text { aac(6')-le- } \\
\text { aph(2')-la } \\
(n=30)\end{array}$ & 6 & 13 & - & 3 & - & - & - & 8 & - \\
\hline
\end{tabular}

Abbreviation: AME, aminoglycoside modifying enzymes.

AMEs such as ant(2')-I, ant(4')-IIb, aac(3')-III, and aac(3')-IV were not encountered in our study isolates but their presence was widely reported in countries like Iran, ${ }^{22}$ France $^{23}$ and China. ${ }^{24}$ The GP AMEs aph(2')-Ib, aph(2')-Ic, and $\operatorname{aph}\left(2^{\prime}\right)$-Id were not encountered in our study; however, their presence was significantly reported in Enterococci and Staphylococcus. ${ }^{14,25}$ This significant difference in their presence of AMEs may be due to usage of antibiotics and other geographical factors involved. ${ }^{19}$

The bifunctional enzyme aac(6')-Ie-aph(2')-Ia that confers high-level resistance to gentamicin, amikacin, tobramycin, netilmicin and is considered more prevalent in Enterococci ${ }^{26}$ has been identified in the present study; there are two previous reports citing its presence and transferability in gram-negative bacteria. ${ }^{8}$ The prevalence of these AMEs in this study is $19.68 \%$ and their transfer indicates their location on conjugative plasmids. However, the prevalence rate is significantly less compared with their rate of occurrence in Enterococci (38.20\%). ${ }^{27}$

\section{Conclusion}

Our findings throw light on the distribution of the different AMEs and their combination among the clinical isolates of gram-negative bacteria. To the best of our knowledge, this is the first report to study the presence of GP AMEs in gram-negative bacteria from India. Considering the transferability potential of these resistance genes between 
gram-positive and gram-negative bacteria frequent surveillance studies are required to study the changing pattern and evolution of resistance among bacteria.

\section{Conflict of Interest}

None.

\section{References}

1 Mohanam L, Menon T. Emergence of rmtC and rmtF 16S rRNA methyltransferase in clinical isolates of Pseudomonas aeruginosa. Indian J Med Microbiol 2017;35(2):282-285

2 Ramirez MS, Tolmasky ME. Aminoglycoside modifying enzymes. Drug Resist Updat 2010;13(6):151-171

3 Shaw KJ, Rather PN, Hare RS, Miller GH. Molecular genetics of aminoglycoside resistance genes and familial relationships of the aminoglycoside-modifying enzymes. Microbiol Rev 1993;57(1):138-163

4 Berçot B, Poirel L, Nordmann P. Updated multiplex polymerase chain reaction for detection of 16S rRNA methylases: high prevalence among NDM-1 producers. Diagn Microbiol Infect Dis 2011;71(4):442-445

5 Vakulenko SB, Mobashery S. Versatility of aminoglycosides and prospects for their future. Clin Microbiol Rev 2003;16(3):430-450

6 Tolmasky ME, Overview of dissemination mechanisms of genes coding for resistance to antibiotics In: Bonomo R, Tolmasky ME eds Enzyme-Mediated Resistance to Antibiotics: Mechanisms, Dissemination, and Prospects for Inhibition Washington, DC: ASM Press; 2007:267-270

7 Shahid M, Malik A. Resistance due to aminoglycoside modifying enzymes in Pseudomonas aeruginosa isolates from burns patients. Indian J Med Res 2005;122(4):324-329

8 Kallová J, Macicková T, Majtánová A, Aghová A, Adam D, Kettner M. Transferable amikacin resistance in gram-negative bacterial isolates. Chemotherapy 1995;41(3):187-192 [AP6]

9 Clinical and Laboratory Standards Institute, Performance Standards for Antimicrobial Susceptibility Testing. CLSI Supplement M100S. CLSI Supplement M100S. Wayne, PA: Clinical and Laboratory Standards Institute; 2016

10 Galani I, Souli M, Daikos GL, et al. Activity of plazomicin (ACHN-490) against MDR clinical isolates of Klebsiella pneumoniae, Escherichia coli, and Enterobacter spp. from Athens, Greece. J Chemother 2012;24(4):191-194

11 Haldorsen BC, Simonsen GS, Sundsfjord A, Samuelsen O, Norwegian Study Group on Aminoglycoside Resistance. Increased prevalence of aminoglycoside resistance in clinical isolates of Escherichia Coli and Klebsiella Spp. in Norway is associated with the acquisition of AAC(3)-II and AAC(6')-Ib. Diagn Microbiol Infect Dis 2014;78(1):66-69

12 Torres C, Perlin MH, Baquero F, Lerner DL, Lerner SA. High-level amikacin resistance inassociated with a 3'-phosphotransferase with high affinity for amikacin. Pseudomonas aeruginosa Int J Antimicrob Agents 2000;15(4):257-263

13 Heuer H, Krögerrecklenfort E, Wellington EM, et al. Gentamicin resistance genes in environmental bacteria: prevalence and transfer. FEMS Microbiol Ecol 2002;42(2):289-302

14 Vakulenko SB, Donabedian SM, Voskresenskiy AM, Zervos MJ, Lerner SA, Chow JW. Multiplex PCR for detection of aminoglycoside resistance genes in Enterococci. Antimicrob Agents Chemother 2003;47(4):1423-1426

15 L Aishwarya KV, Geetha PV, Shanthi M, Uma S. Co-occurrence of two 16S rRNA methyltransferases along with NDM and OXA 48 like carbapenamases on a single plasmid in Klebsiella pneumoniae. J Lab Physicians 2019;11(4):305-311

16 Pérez-Pérez FJ, Hanson ND. Detection of plasmid-mediated AmpC $\beta$-lactamase genes in clinical isolates by using multiplex PCR. J Clin Microbiol 2002;40(6):2153-2162

17 Wang $\mathrm{H}$, Chen M, Ni Y, et al. Antimicrobial resistance among clinical isolates from the Chinese Meropenem Surveillance Study (CMSS), 2003-2008. Int J Antimicrob Agents 2010;35(3):227-234

18 Ghotaslou R, Yeganeh Sefidan F, Akhi MT, Asgharzadeh M, Mohammadzadeh Asl Y. Dissemination of genes encoding aminoglycoside-modifying enzymes and arm A amongisolates in Northwest Iran. Enterobacteriaceae Microb Drug Resist 2017;23(7):826-832

19 Hu X, Xu B, Yang Y, et al. A high throughput multiplex PCR assay for simultaneous detection of seven aminoglycoside-resistance genes in Enterobacteriaceae. BMC Microbiol 2013;13(1):58

20 Miró E, Grünbaum F, Gómez L, et al. Characterization of aminoglycoside-modifying enzymes in Enterobacteriaceae clinical strains and characterization of the plasmids implicated in their diffusion. Microb Drug Resist 2013;19(2):94-99

21 Martin P, Jullien E, Courvalin P. Nucleotide sequence of Acinetobacter baumannii aphA-6 gene: evolutionary and functional implications of sequence homologies with nucleotide-binding proteins, kinases and other aminoglycoside-modifying enzymes. Mol Microbiol 1988;2(5):615-625

22 Mokhtari H, Eslami G, Zandi H, Dehghan-Banadkouki A, Vakili M. Evaluating the frequency of aac ( $\left.6^{\prime}\right)$-IIa, ant (2")-I, intl1, and intl2 genes in aminoglycosides resistantisolates obtained from hospitalized patients in Yazd, Iran. Klebsiella pneumoniae Avicenna J Med Biotechnol 2018;10(2):115-119

23 Dubois V, Arpin C, Dupart V, et al. Beta-lactam and aminoglycoside resistance rates and mechanisms among Pseudomonas aeruginosa in French general practice (community and private healthcare centres) J Antimicrob Chemother 2008;62(2):316-323

24 Zhang XY, Ding LJ, Fan MZ. Resistance patterns and detection of $\operatorname{aac}\left(3^{\prime}\right)$-IV gene in apramycin-resistant Escherichia coli isolated from farm animals and farm workers in northeastern of China. Res Vet Sci 2009;87(3):449-454

25 Kao SJ, You I, Clewell DB, et al. Detection of the high-level aminoglycoside resistance gene aph(2")-Ib in Enterococcus faecium. Antimicrob Agents Chemother 2000;44(10):2876-2879

26 Behnood A, Farajnia S, Moaddab SR, Ahdi-Khosroshahi S, Katayounzadeh A. Prevalence of aac(6')-Ie-aph(2")-Ia resistance gene and its linkage to Tn5281 in Enterococcus faecalis and Enterococcus faecium isolates from Tabriz hospitals. Iran J Microbiol 2013;5(3):203-208

27 Padmasini E, Padmaraj R, Ramesh SS. High level aminoglycoside resistance and distribution of aminoglycoside resistant genes among clinical isolates ofspecies in Chennai, India. Enterococcus ScientificWorldJournal 2014;2014:329157 